\title{
STUDY ON THE THERMAL PERFORMANCE OF EVACUATED SOLAR COLLECTOR SYSTEM
}

\author{
Fouda T. Z. ${ }^{*}$ M. Darwesh ${ }^{* *}$ and N. Gremida ${ }^{* * *}$
}

\begin{abstract}
The experimental work was carried out in Faculty of Agriculture, Tanta University, Egypt, which located at latitude and longitude angle of $30.49^{\circ} \mathrm{N}$ and $30.59^{\circ} \mathrm{E}$, respectively, during winter and summer seasons 2015. The experiments were designed to evaluate the thermal performance of evacuated tube solar water collector ETC with 20 evacuated tubes, tank capacity 150 liters and net surface area of $1.5 \mathrm{~m}^{2}$. The thermal efficiency for evacuated tube solar collector depends on the solar radiation, ambient temperature from sunrise to sunset. The obtained results showed that the maximum outlet water temperatures were 63 and $85.7^{\circ} \mathrm{C}$ during winter and summer seasons, respectively. Also, the differences between outlet water temperatures and ambient air temperatures were 46.2 and $50.1{ }^{\circ} \mathrm{C}$, and the temperature differences between outlet water temperature and inlet water temperature from sunrise to sunset were 17.09 and $17.30^{\circ} \mathrm{C}$ during two different seasons. While, the overall efficiency values were 77.20 and $79.90 \%$. In addition, the linear regression analysis showed that the absorbed solar energy $\left(Q_{a}\right)$ was a function in available solar radiation $(Q)$. Therefore, can be estimated the values of absorbed solar energy from the following equation: $Q_{a}=0.818 Q,\left(R^{2}=0.999\right)$.
\end{abstract}

\section{INTRODUCUTION}

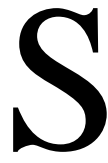
olar water heaters use the solar energy from the sun to generate heat which can then be used to heat water. The evacuated tube and heat pipe technology provides very efficient and reliable solar thermal production in an easy to install, low maintenance design. Evacuated tube collectors tube consist of glass vacuum sealed tubes with absorber surface located in the inner glass tube having different shapes.

\footnotetext{
* Prof Agric. Eng.,Dept ., Fac. Agric., Tanta U., Egypt

**Assoc.Prof Agric. Eng.,Dept., Fac. Agric., Tanta U., Egypt

*** Lect. Agric. Eng.,Dept., El-Geran High Inst., of Agric- Tiroply- Libya
} 
Gunerhan (2007) noted that, the optimum collector orientation is south facing and the optimum tilt depends upon the latitude and the day of the year. In winter months, the optimum tilt is greater (usually latitude $+15^{\circ}$ ), whilst in summer months, the optimum tilt is less (usually latitude $-15^{\circ}$ ). Zhang and Yamaguchi (2008) Indicated that, investigations have been conducted to characterize the overall performance of water-in-glass evacuated tube collectors and the results show that the overall efficiency is in the range of 50 to $60 \%$. Budihardjo and Morrison (2009) showed that, the performance of a typical 30 tube evacuated tube array was lower than a typical 2 panel flat plate array for domestic water heating in Sydney. Also found that, the annual solar fraction of the water-in-glass system with $45^{\circ}$ collector inclination was only $1.5 \%$ higher than the solar fraction with a standard $22{ }^{\circ}$ collector inclination. Grigonienè and Karnauskas (2009) noted that in Lithuania, the optimal angle of tilt of a solar collector is determined experimentally is $15^{\circ}$ to $60^{\circ}$ for the whole year, where, $15^{\circ}$ to $45^{\circ}$ in winter and $30^{\circ}$ to $60^{\circ}$ in summer. Hayek et al. (2011) used that, two kinds of evacuated tube solar collectors, namely, the water-in-glass tubes and the heat-pipe designs. The experiments were carried out during the period of November to January. The results show that the heat-pipe-based collectors are better than the water-in-glass designs and their efficiency is almost 15 to 20\% higher. REN21.(2012) noted that, the solar thermal technologies significantly contribute to hot water production in several countries. In fact, the global solar hot water installed capacity at the end of 2011 was estimated in 232 GWth with an increase in the last year (2010-11) of 44.3 GWth of which 42.4GWth were due to glazed systems and the rest to unglazed systems. Muzioa et al.(2014) stated that, characterization of an evacuated $1.3 \mathrm{~m}$ long, tubular solar collector are presented. The higher thermal expansion coefficient of the steel tube as compared to the glass jacket. Also the collector can develop an efficiency of $50 \%$ at $150{ }^{\circ} \mathrm{C}$, with a concentration factor of 6.5 . Nogueira et al. (2015) used that, solar collector dimensions 1.6 x $2.6 \mathrm{~m}$. It was installed facing north, with a $28^{\circ}$ inclination, of the type all glass is made up of 20 glass tubes, directly connected to thermal reservoir. The efficiency of the collector was, resulting in a mean value of $51 \%$. Wanget al. (2015) studied the thermal efficiency of evacuated tubes collector 
under the: ambient temperature 14 to $20{ }^{\circ} \mathrm{C}$, solar irradiation 890 to 960 $\mathrm{W} / \mathrm{m}^{2}$, wind speed less than $3 \mathrm{~m} / \mathrm{s}$. They found that average temperature of working fluid reached $150{ }^{\circ} \mathrm{C}$, the instantaneous solar thermal efficiency was still as high as $50.2 \%$. Darwesh (2015) compared between evacuated tube and flat plate solar collector with two different tilt angles $\left(30.5^{\circ}\right.$ and $\left.45.3^{\circ}\right)$. In addition, he found that the tilt angle of $45.3^{\circ}$ increased the available solar energy, absorbed solar energy, useful heat gain and overall efficiency by $16.52 \%, 15.65 \%, 32.84 \%$ and $8.57 \%$, respectively, as compared with $30.5^{\circ}$ tilt angle.

The main objectives of the present study were to investigate the effect of both solar radiation, ambient temperature from sunrise to sunset on the thermal efficiency for evacuated tube solar collector during winter and summer seasons.

\section{MATERIALS AND METHODS}

The experimental work was executed in, Egypt (latitude and longitude angles are $30.49^{\circ} \mathrm{N}$ and $30.59^{\circ} \mathrm{E}$ ) during winter and summer 2015 . The thermo-syphon evacuated tube solar collector was functioned during this experimental work. The solar collector is situated on the roof of the Faculty of Agriculture

\section{Evacuated tube collector (ETC)}

-Evacuated solar collector is consists of 20 evacuated tubes made of borosilicate glass, $180 \mathrm{~cm}$ long mounted on a movable steel frame, and a horizontal tank (150 liters) as shown in Fig.(1).

-Evacuated tube is composed of two coaxial borosilicate glass tubes jointed at the top and sealed at the bottom which contain a vacuum, the outer of $58 \mathrm{~mm}$ diameter and the inner $47 \mathrm{~mm}$ diameter each tube of evacuated solar collector contains 2.6 liters of water. The inner tube contains the water to be heated and its exterior is coated with a suitably dark absorbing material (nitrite aluminum) for collecting the maximum possible incident solar radiation which converting into heat and transferring to working fluid (water). The space between the outer and inner tube is being evacuated and using as a thermal insulator to reduce convection and conduction heat losses. The cross sections of glass evacuated tube as shown in Fig.(2). 
-The storage tank is equipped with an electrical heater to provide hot water at desired level for different applications when the intensity of solar radiation is insufficient to provide that level.
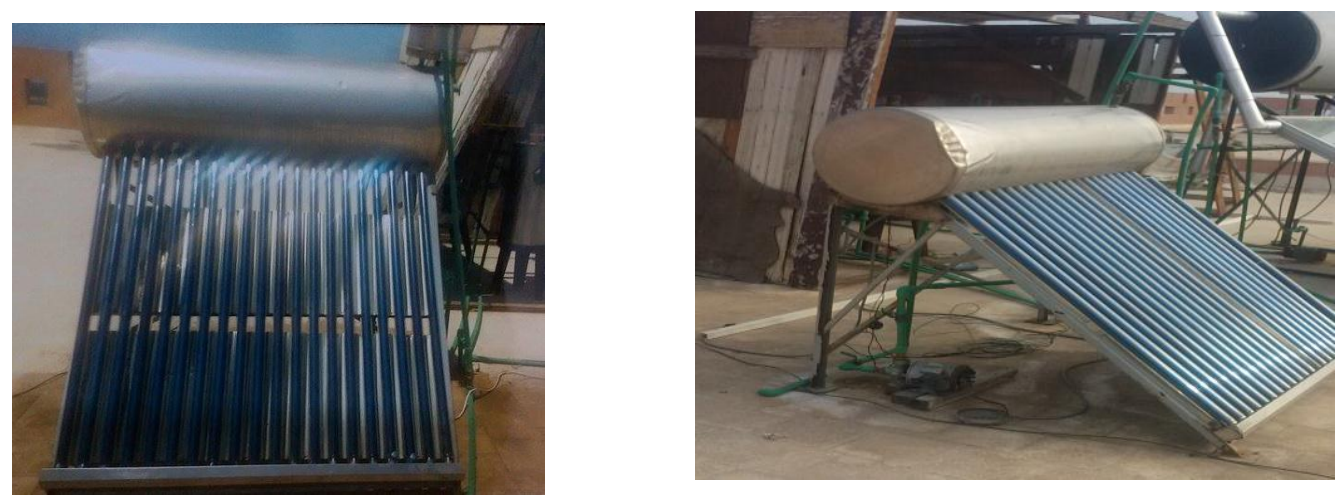

Fig. (1). Photo of evacuated tube header collector

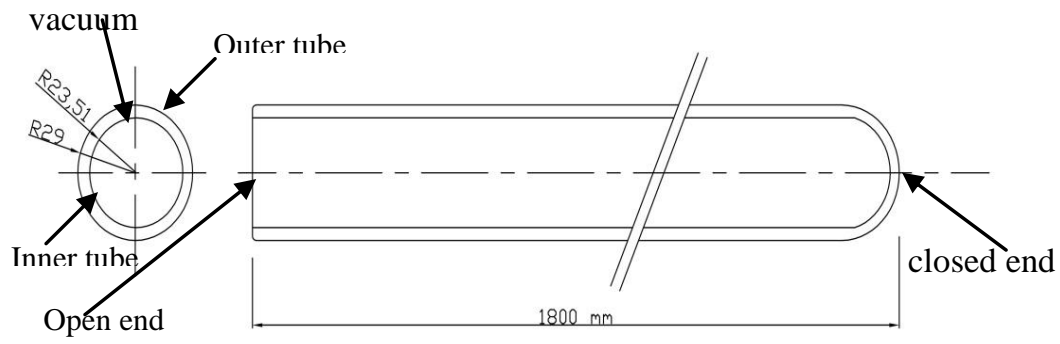

Fig. (2). Schematic diagram of cross-section of one ended evacuated tube.

-Tilt angle was used in the present study $45.3^{\circ}$ with horizontal surface. The solar collector was orientated to south direction and fixed

\section{Instruments}

-Thermocouples were employed to measure the inlet and outlet water temperatures of collector.

-Data logger the sensors were connected with a data logger system, PC and software programs to display and record data

-A digital solar power meter (TENMARS) TM-207 was used to measure the solar radiation flux incident with Accuracy: typically within \pm $10 \mathrm{~W} / \mathrm{m}^{2}$ or $\pm 5 \%$, whichever is greater in sunlight; additional temperature induced error $\pm 0.38 \mathrm{~W} / \mathrm{m}^{2} /{ }^{\circ} \mathrm{C}$, resolution $1 \mathrm{~W} / \mathrm{m}^{2}$ and range $1999 \mathrm{~W} / \mathrm{m}^{2}$. 


\section{-The thermal performance of evacuated solar collector}

The optimums tilt angle was calculated for the stationary non-tracking solar collector, using the following equation (Duffie and Beckman, 2006):

$\boldsymbol{\beta}_{0} \quad \boldsymbol{\Phi}-\boldsymbol{\delta}, \quad$ degree

Where: $\Phi$ is the latitude angle and $\delta$ is the declination angle in degree.

The parameters of the thermal performance test and the relationship between them were examined and tested by Duffie and Beckman (1991). The solar energy available $(\mathbf{Q})$ could be calculated as a function of solar radiation flux incident $(\mathrm{R})$ and solar heater surface area (Ac) as follows:

$$
\mathbf{Q}=\mathbf{R} \text { Ac, } \mathbf{W} \text {. }
$$

The absorbed solar radiation $\left(\mathbf{Q}_{\mathbf{a}}\right)$ could be computed in terms of transmittance of glass cover $(\tau)$ and the absorptance of the absorber plate $(\alpha)$ as follows: $\quad \mathbf{Q a}=\tau \boldsymbol{\alpha} \mathbf{Q}, \mathbf{W}$

The absorption efficiency ( $\boldsymbol{\eta}$ a) could be determined as follows:

$$
\eta_{\mathbf{a}}=(\mathbf{Q} / \mathbf{Q}) \times 100, \% \text {. }
$$

The useful heat gain to storage $\left(\mathbf{Q}_{c}\right)$ could be estimated as a function of the mass flow rate of water $\left(\mathrm{C}_{\mathrm{p}}\right)$, and temperature difference between outlet $\left(\mathrm{T}_{\mathrm{fo}}\right)$ and inlet $\left(\mathrm{T}_{\mathrm{fi}}\right)$ water temperatures as follows:

$$
Q c=m C_{p}\left(T_{\text {fo }}-T_{\text {fi }}\right), W \text {. }
$$

The heat transfer efficiency $(\eta \mathrm{h})$ could be calculated as follows:

$$
\eta_{h}=\left(Q_{c} / Q_{a}\right) \times 100, \%
$$

The overall thermal efficiency can be estimated from the following equation by Hayek (2011)

$$
\boldsymbol{\eta}=\mathbf{Q}_{\mathrm{c}} / \mathbf{Q}
$$

The normalized temperature rise $\left(\mathbf{D}_{\mathrm{T}}\right)$ could be estimated in terms of the temperature difference between the inlet water $\left(\mathrm{T}_{\mathrm{fi}}\right)$ and the ambient temperature $\left(\mathrm{T}_{\mathrm{a}}\right)$ as follows: $\mathbf{D}_{\mathrm{T}}=\left(\mathbf{T}_{\mathrm{fi}}-\mathbf{T}_{\mathbf{a}}\right) / \mathbf{R},{ }^{\circ} \mathbf{C} \cdot \mathbf{m}^{2} / \mathbf{W}$.

The solar energy stored in the storage tank $\left(\mathbf{Q}_{\mathrm{s}}\right)$ could be computed as a function of mass of water in the storage tank per unit time $\left(\mathrm{m}_{\mathrm{s}}\right)$, specific heat of water $\left(\mathrm{C}_{\mathrm{p}}\right)$, and the temperature difference between mean tank at sunset time $\left(\mathrm{T}_{\mathrm{k} 2}\right)$ and sunrise time $\left(\mathrm{T}_{\mathrm{k} 1}\right)$ as follows:

$$
\text { Qs }=\text { ms Cp }\left(\mathbf{T}_{\mathrm{k} 2}-\mathbf{T}_{\mathrm{k} 1}\right), \mathrm{W} \text {. }
$$

The storage system efficiency $\left(\boldsymbol{\eta}_{\mathrm{s}}\right)$ can be found as follows:

$$
\eta s=\left(Q_{s} / Q_{c}\right) \times 100, \% \text {. }
$$


The same net power output can be written by (Duffie and Beckman, 2006) in terms of quantities representing the heat transfer mechanism, or the heat input minus the heat losses, as

$$
\mathbf{Q}_{\mathbf{c}}=\operatorname{Ac~FR}\left[\mathbf{R}-\mathbf{U L}\left(\mathbf{T}_{\mathbf{m}}-\mathbf{T}_{\mathrm{a}}\right)\right]
$$

Where FR is the collector heat removal factor and UL is the overall heat transfer coefficient, Tm is a mean temperature of the working fluid flowing inside the collector, generally taken as the average between the inlet and outlet temperatures of the collector.

Combining the heat rate given by equation (11) with the definition of the efficiency, and nothing that UL is generally a function of temperature, leads to the following expression by Hayek (2011)

$$
\boldsymbol{\eta}=\boldsymbol{\eta} \mathbf{0}-\mathbf{a}(\mathbf{T m}-\mathbf{T a}) / \mathbf{R}-\mathbf{b}(\mathbf{T} \mathbf{m}-\mathbf{T a})^{\mathbf{2}} / \mathbf{R}
$$

in which, ๆo is an intercept (maximum) efficiency or optical efficiency Take from solar collector specification, $a$ is a negative of first order loss coefficient in $\mathrm{W} / \mathrm{m}^{2} / \mathrm{K}$ - Take from solar collector specification and $\mathrm{b}$ is a negative of second order loss coefficient in $\mathrm{W} / \mathrm{m}^{2} / \mathrm{K}$ - Took from solar collector specification as shown in Table (1).

Table (1): Solar collector specification

\begin{tabular}{|l|l|}
\hline Parameters & ETC \\
\hline Intercept (maximum) efficiency & $0.819(\alpha=0.90, \tau=0.91)$ \\
\hline Negative of first order loss coefficient & $1.7 \mathrm{~W} / \mathrm{m}^{2} / \mathrm{K}$ \\
\hline Negative of second order loss coefficient & $0.008 \mathrm{~W} / \mathrm{m}^{2} / \mathrm{K}$ \\
\hline Net collector area & $1.5 \mathrm{~m}^{2}$ \\
\hline
\end{tabular}

\section{RESULTS AND DISCUSSION}

Daily total solar radiation and available solar energy for two seasons.

Solar radiation flux incident on tilted solar collector is the effective element uses to determine thermal performance of evacuated solar collector. The data of solar radiation were collected in two different seasons (winter and summer). The daily average total solar radiation flux incidents on the tilted surface were $5.604 \mathrm{~kW} \mathrm{~h} / \mathrm{m}^{2} /$ day and 7.34 $\mathrm{kWh} / \mathrm{m}^{2} /$ day during winter and summer seasons, respectively. The hourly averages measured were $701 \mathrm{~W} / \mathrm{m}^{2}$ and $918 \mathrm{~W} / \mathrm{m}^{2}$ during winter and summer seasons, respectively. The higher values for solar radiation observed $\left(1247\right.$ and $\left.1299 \mathrm{~W} / \mathrm{m}^{2}\right)$ at noon. The previous result because solar 
incidence angle at this time was lower than other times as shown in Fig.(3) The values of solar radiation in winter season nearly to the values of solar radiation in summer season. This result reveled that evacuated solar collector was fixed at $45^{\circ}$ tiltangle. The difference between this angle and optimum tilt angle in February is $1.5^{\circ}$.mean whiles the difference between this angle and optimum tilt angle on September $17^{\circ}$.

Fig.(4) showed that, the hourly average solar energy available throughout daylight during two seasons. The daily average solar energy values of $8.406 \mathrm{kWh} /$ day and $11.011 \mathrm{kWh} /$ day during winter and summer months, respectively.

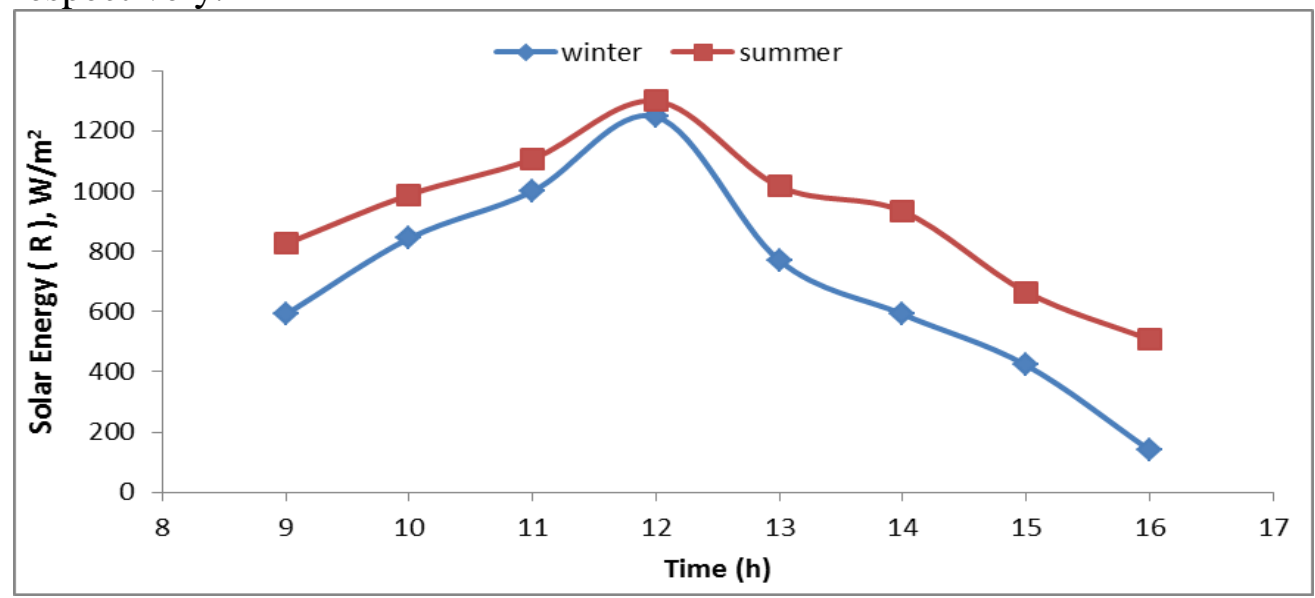

Fig.(3)Hourly average total solar radiation flux incident on the tilted surfaces for two seasons.

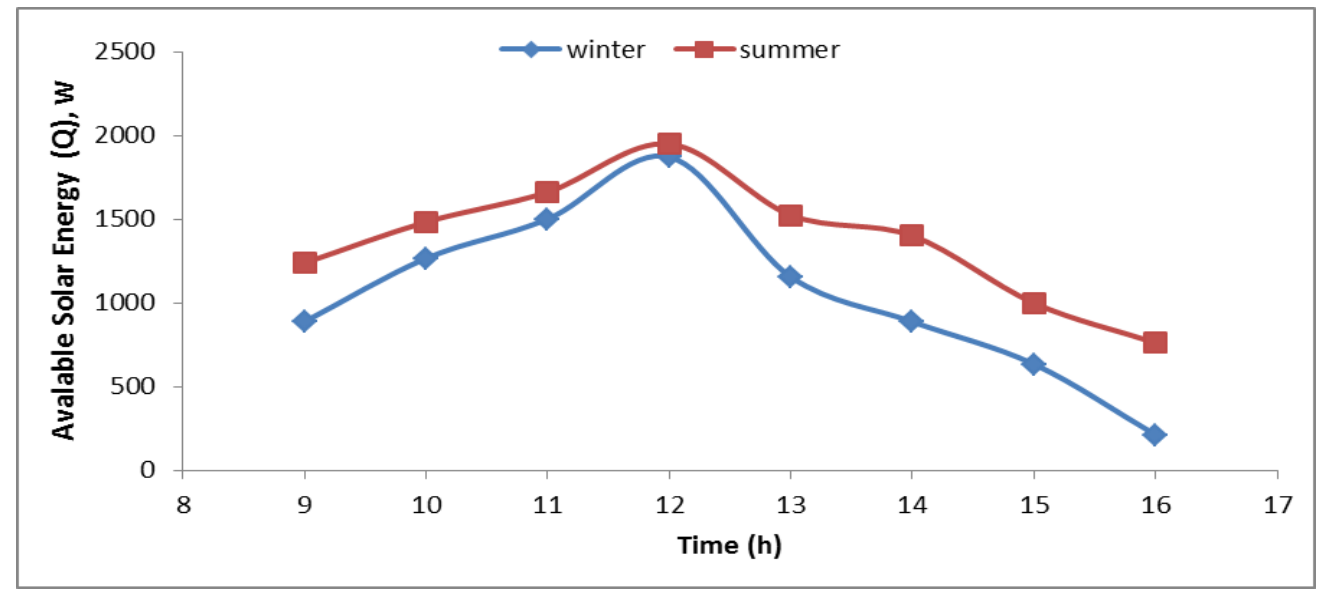

Fig. (4) Hourly average available solar energy on the tilted surfaces for two seasons 


\section{Daily absorbed solar energy and useful heat gain for two seasons.}

Fig.(5) illustrated that, the relationship between absorbed solar energy and time during two different seasons under experimental work. The daily average solar energy 6.885 and $9.017 \mathrm{kWh} /$ day. The hourly average values of useful heat gain to storage were 6.127 and $8.485 \mathrm{kWh} /$ day during two seasons. Also, the useful heat gain to storage values in winter season were greater than it $s$ in summer as shown in Fig.6. The previous results revealed that the temperature difference between

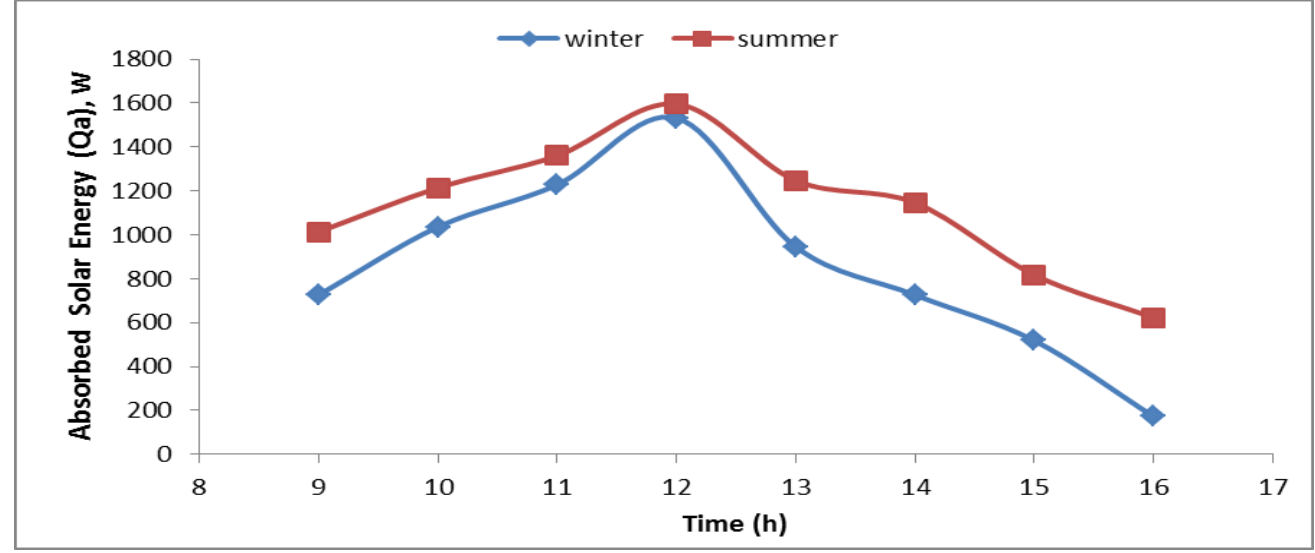

Fig.(5) Hourly average absorbed solar energy for two seasons

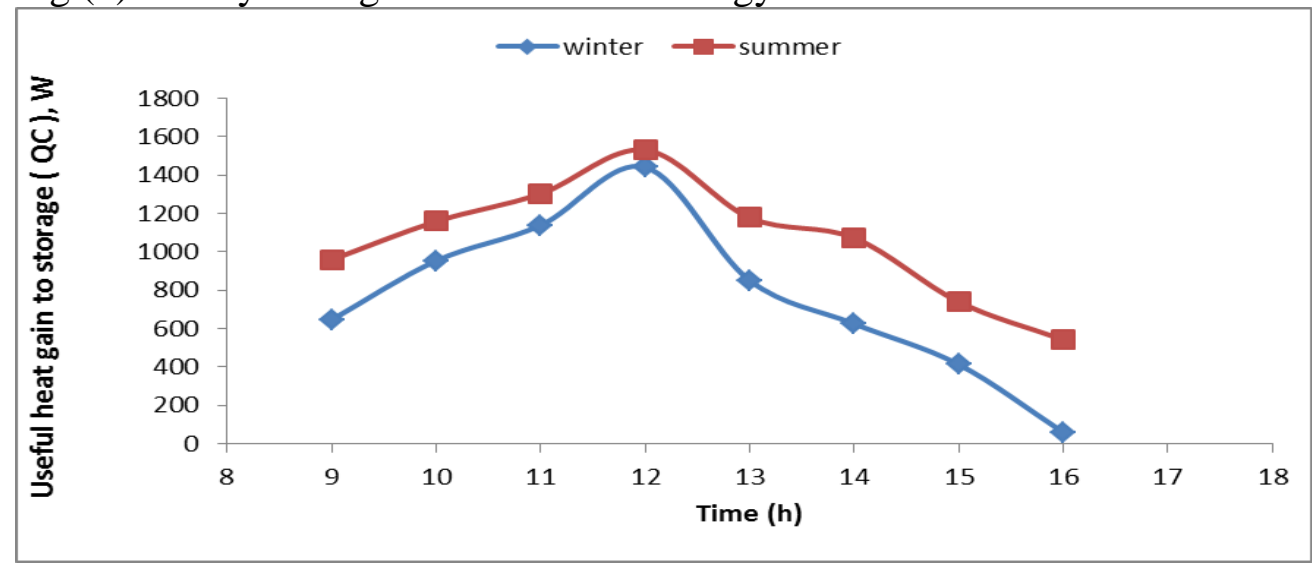

Fig.(6) The relationship between useful heat gain to storage and time during two different seasons

Solar collector heat losses and heat transfer efficiency for two seasons.

The daily average solar collector heat losses values were 0.757 and 0.532 $\mathrm{kWh} /$ day in winter and summer seasons as shown in Fig.7. These losses 
in winter greater than summer season more than winter season because ambient air temperature differs between two seasons. The heat losses from the solar collectors were highly affected by the water inlet temperature and ambient air temperature surrounding the collectors. Fig.(8) described the behavior of the heat transfer efficiency throughout daylight during winter and summer seasons. The maximum values of heat transfer efficiency were $82 \%$ and $93 \%$ during winter and summer seasons, respectively.

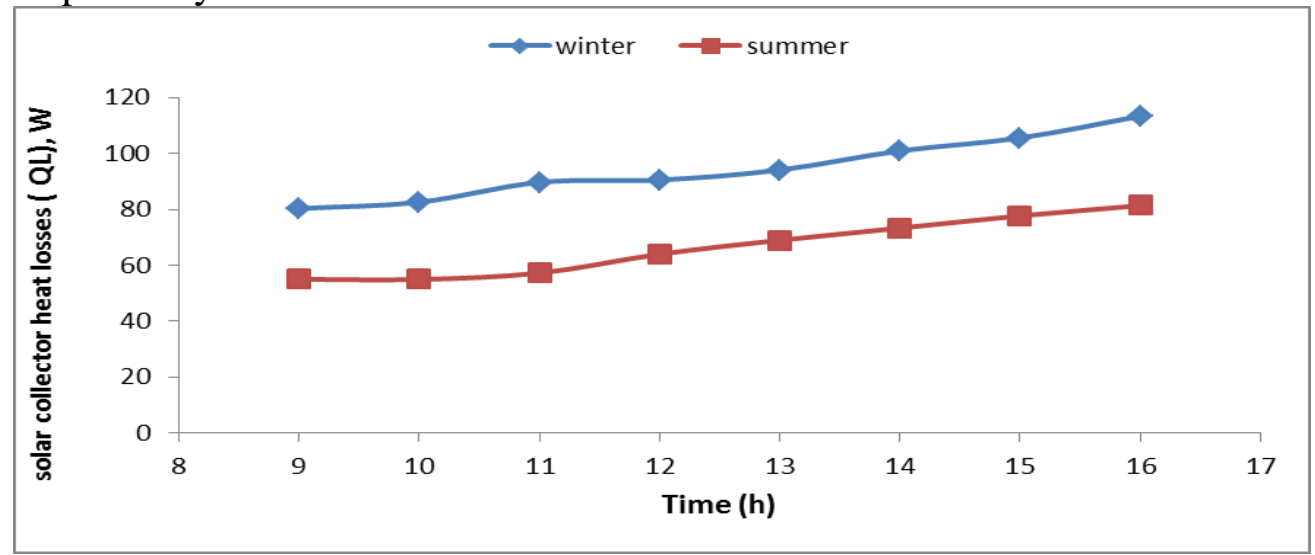

Fig.(7) The hourly average solar collector heat losses in different two seasons

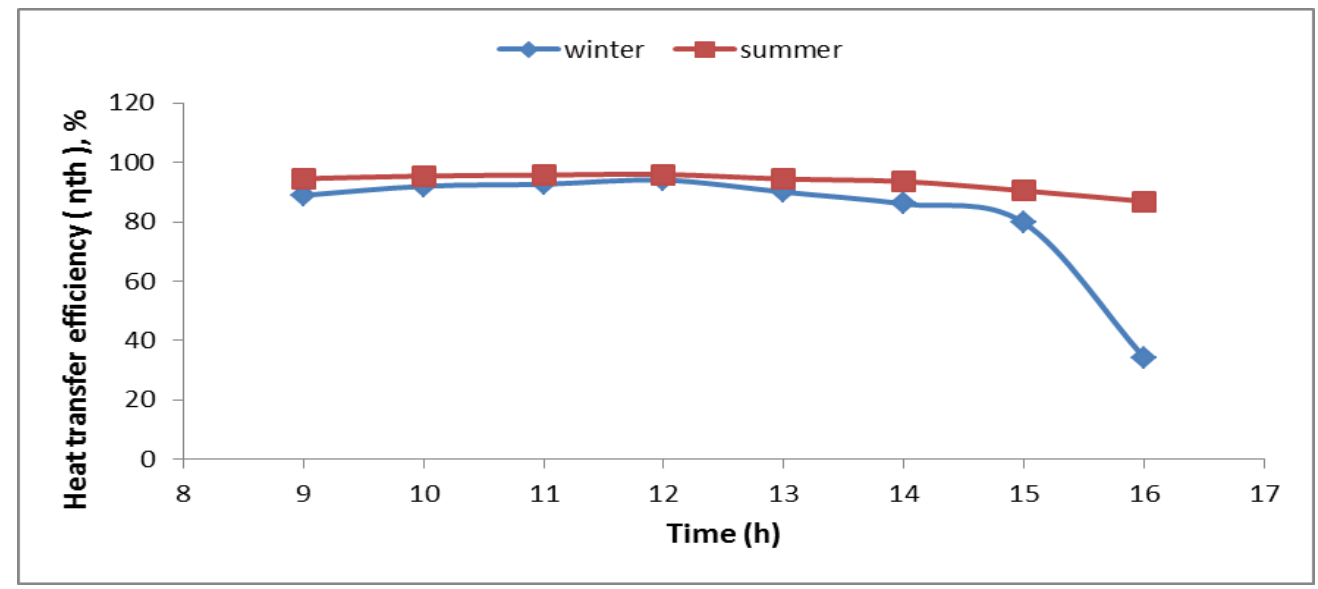

Fig.(8) The heat transfer efficiency in different two seasons

Solar collector energy storage and thermal efficiency for two seasons.

Fig.(9) illustrate the relationship the hourly average solar energy storage during daylight for both of summer and winter seasons. The daily average solar energy storage values of $0.776 \mathrm{kWh} /$ day and $0.755 \mathrm{kWh} /$ day during 
winter and summer respectively. The daily average solar energy storage depend on the temperature difference between outlet water temperature and inlet water temperature. Fig.(10) indicated the relationship between the daily average overall thermal efficiency and day time.

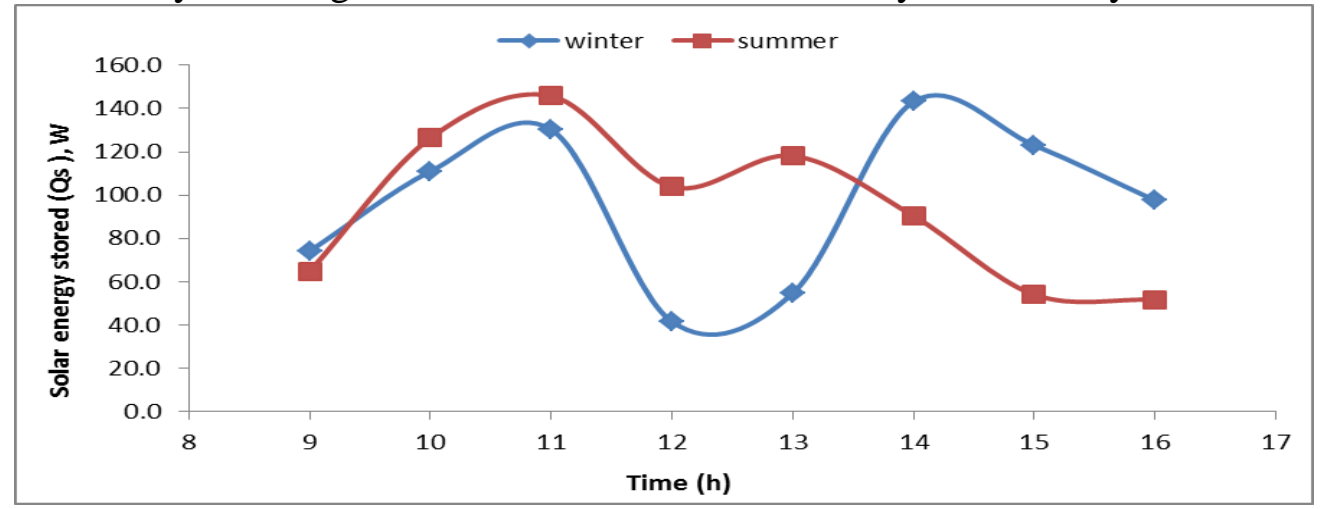

Fig.(9). Solar energy stored during day light in different two seasons

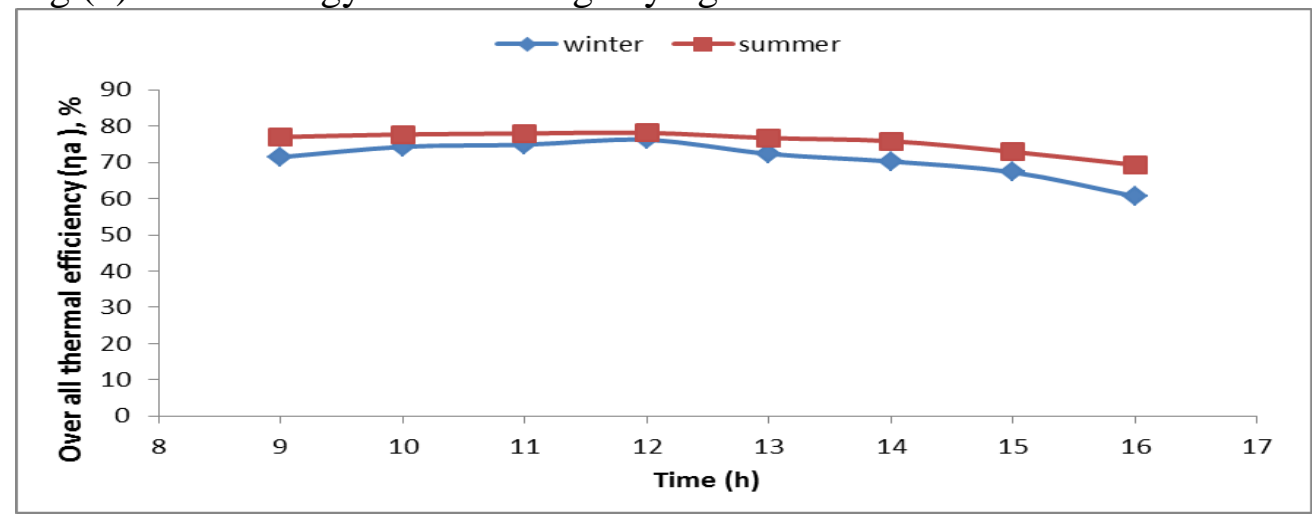

Fig.(10) The overall thermal efficiency throughout day light in different two seasons

The daily average overall thermal efficiency values of $71 \%$ and $76 \%$ during winter and summer respectively. Also, showed that, maximum values at noon were $76 \%$ and $78 \%$ during winter and summer season respectively.

Solar collector temperature differences and outlet water temperature for two seasons.

The hourly average temperature differences between water outlet temperature and water inlet temperature throughout daylight during two different seasons as shown in Fig.(11). The daily average temperature 
differences values were $3.97^{\circ} \mathrm{C}$ and $1.785^{\circ} \mathrm{C}$ during winter and summer respectively. The values of temperature differences in winter and summer seasons at noon it nearly were $3.18^{\circ} \mathrm{C}$ and $3.28^{\circ} \mathrm{Crespectively.}$

Fig.(12) indicated that the hourly average of outlet water temperature $\left(\mathrm{T}_{\mathrm{fo}}\right)$ from sunrise to sunset during winter and summer seasons. The daily average of water outlet temperature values were $55.61^{\circ} \mathrm{C}$ and $60.557^{\circ} \mathrm{C}$ during winter and summer respectively. Also, Fig.(12) showed that, the outlet water temperature increased during the operation of the system from the beginning of operation of the system at 9:00 until the end of operation of the system at $16: 00 \mathrm{pm}$. The values were from $\left(49.3{ }^{\circ} \mathrm{C}\right.$ to $\left.61.7^{\circ} \mathrm{C}\right)$ and from $\left(52.9\right.$ to $\left.66.1^{\circ} \mathrm{C}\right)$ during winter and summer respectively.

The relationship between absorbed solar energy and solar energy available

Fig.(13) showed that the relationship between absorbed solar energy $\left(Q_{a}\right)$ and solar energy available (Q). The relationship between absorbed solar energy and solar energy available was relationship direct proportion (linear relation).

The following equation describes the relationship:

$Q_{a}=0.818 Q,\left(R^{2}=0.99\right)$.

Where 0.82 is optical efficiency $(\alpha \tau)$.

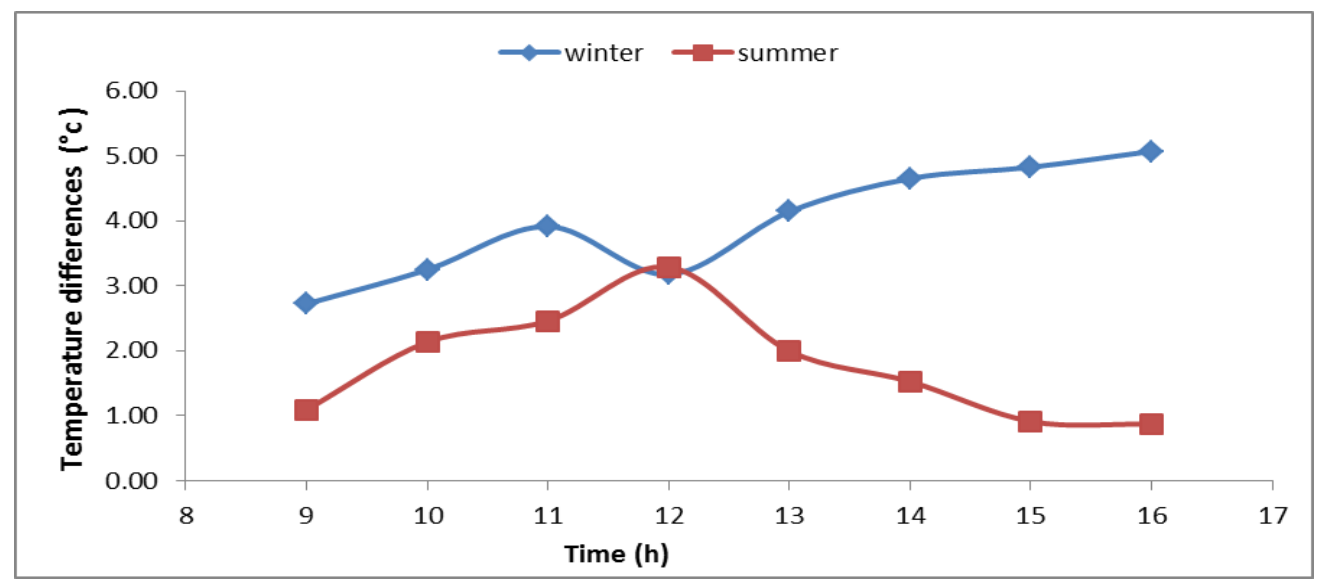

Fig.(11).The hourly average of temperature differences for two seasons. 


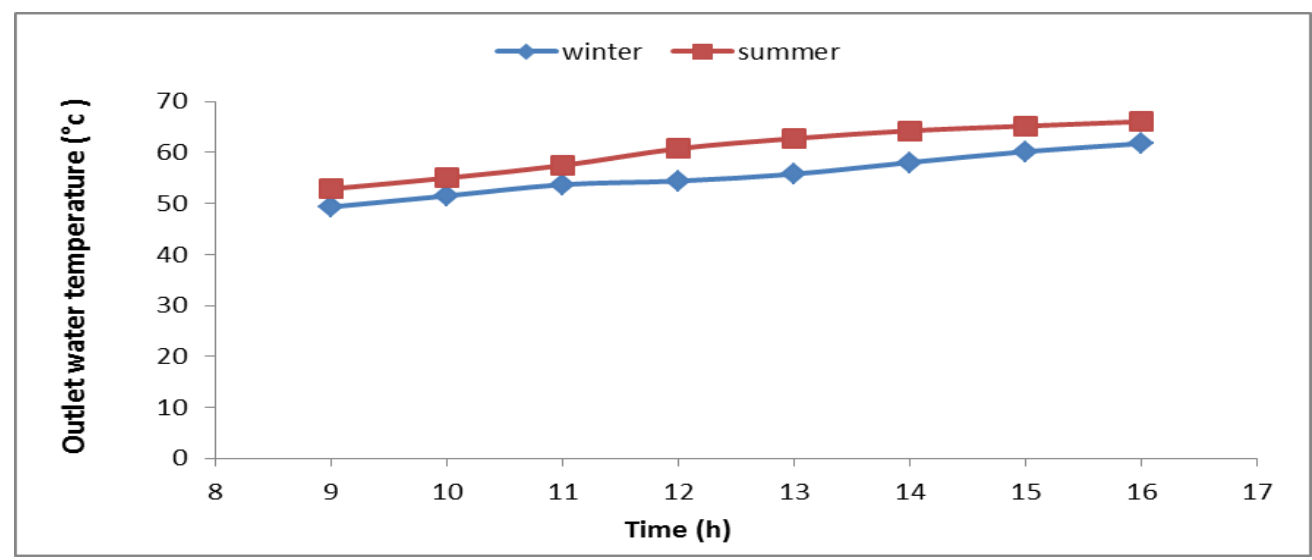

Fig.(12)The water outlet temperature with time in different two seasons.

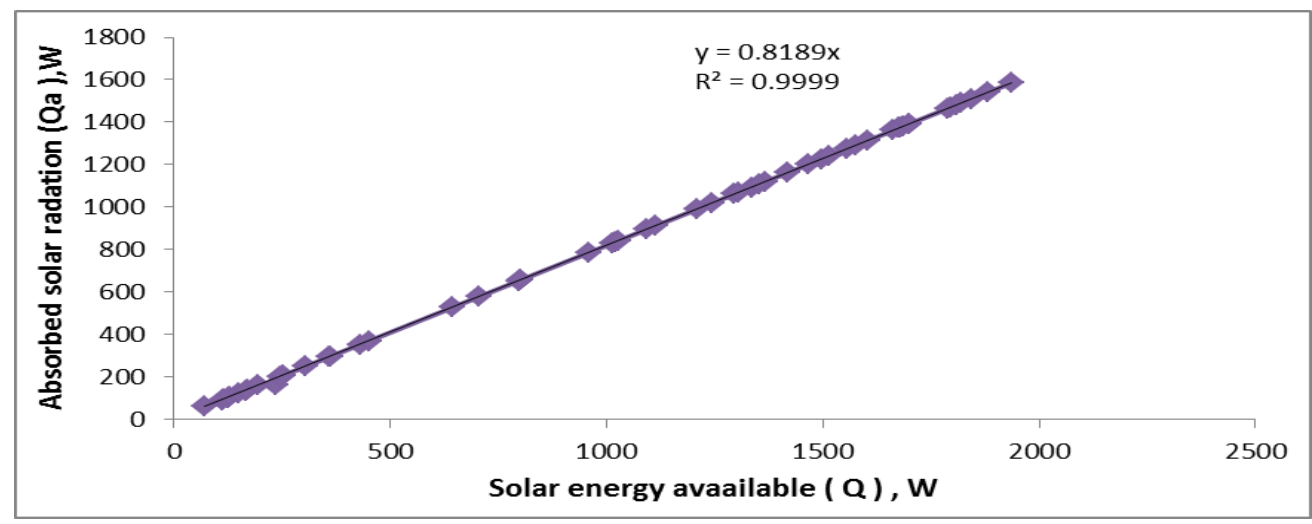

Fig.(13): Absorbed solar radiation against solar energy available in different two seasons.

\section{CONCLUSION}

The obtained data of this experimental work can be summarized and concluded as follows:

1- The amount of solar radiation flux incident on tilted solar collectors affecting on the items of thermal performance analysis during winter and summer seasons.

2- The air temperature governed of solar collector heat losses during different two seasons.

3- The solar collector can be absorbed $82 \%$ from the solar energy available depend upon the optical efficiency of the evacuated tube solar collector. 


\section{REFERENCES}

Budihardjo, I. and G.L. Morrison., (2009) Performance of water-inglass evacuated tube solar water heaters. Solar Energy 83, 49-56.

Darwesh, M. (2015). Thermal performance test of evacuated tube and falt plate solar collectors under climatic conditions of Egypt. Misr. J. Ag. Eng., 32(4): In press.

Grigonienè, J and M. Karnauska(2009)Mathematical modeling of optimal tilt angles of solar collector and sunray reflector,energetika. 2009. T. 55. Nr. 1. P. 41-46.

Gunerhan, H. (2007) Determination of the optimum tilt angle of solar collectors for building applications. Building and Environment, 42, 779-783.

Hayek, M.; J. Assaf; and W. Lteif,(2011)Experimental Investigation of the Performance of Evacuated-Tube Solar Collectors under Eastern Mediterranean Climatic Conditions,Energy Procedia 6, 618-626.

Muzioa, A.: I. Lizama ; D. Maciasa; G.Oskama; A. Cahuea; R. de Cossa; J.J. Alvarado-Gila; and C. Cortesb. ( 2014 )Characterization of thermal losses in an evacuated tubular solar collector prototype for medium temperature applications, Energy Procedia 57, $2121-2130$.

Nogueira, C; G. Arnauts; J.Neves,; and S. Souza (2015)Technicaleconomical evaluation of a solar water heater with vacuum tubes collector, used in a rural area in Paraná, Brazil, African Journal of Agricultural Research, Vol. 10(17), pp. 1929-1937, 23 April.

REN21.( 2012) Renewables 2012 Global Status Report.

Wang, J.; Z. Yina; J. Qia; G. Mab and X. Liub (2015) Mediumtemperature solar collectors with all-glass solar evacuated tubes, Energy Procedia 70 , $126-129$.

Zhang X.R .and H. Yamaguchi, (2008) An experimental study on evacuated tube solar collector using supercritical CO2, Applied Thermal Engineering, 28:1225-1233. 


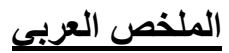

\section{دراسة الاداء الحرارى لنظام المجمع الثمسى المفرغ}

\section{ا.د طارق فودة، د.محمد درويش و م .نسرين قريميدة}

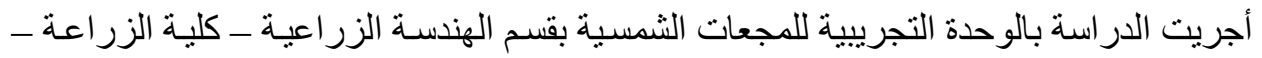

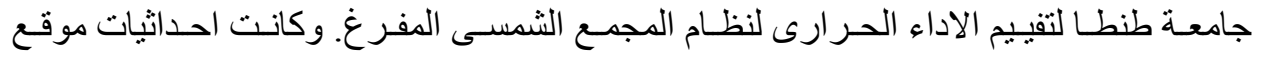
التجربة هي : خط عرض (30.49º N ) وخط طول (30.59² )

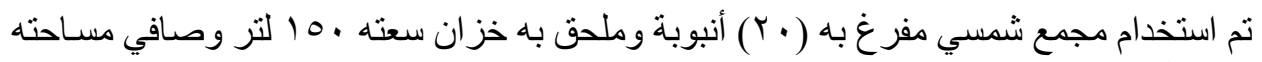

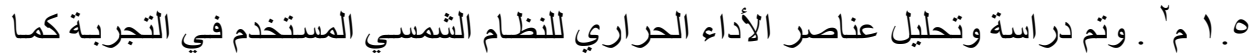

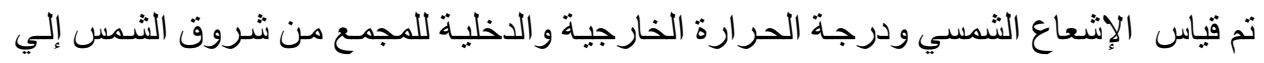

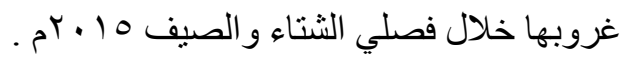
وقد توصلت الار اسة إلى النتائج الآتية: - اقصي درجة حرارة خارجة من المجمع الشمسي كانت سج ، و الصيف علي التو الي.

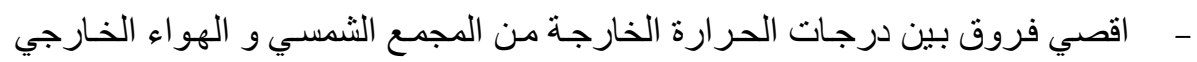

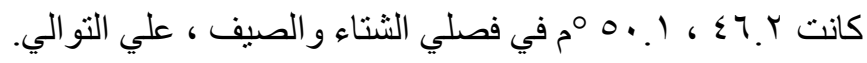
- أقسي فروق في درجـات الحرارة خـلال سـاعات النهار ببين درجـات الحر ارة الميـاه

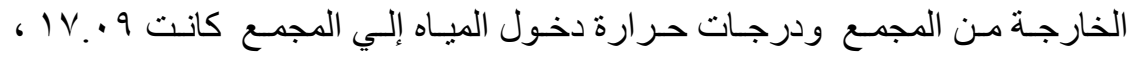

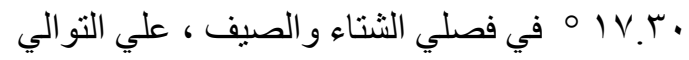

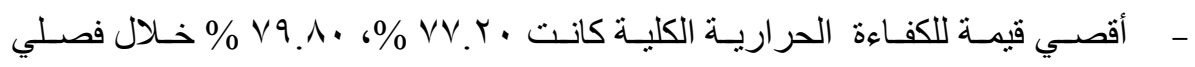

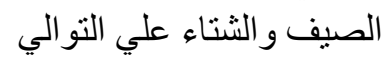

أوضحت النتائج أن الطاقة الثمسية الممتصة هي دالـة في الطاقة الثمسية المتاحـة ولذلك امكن استنتاج المعادلة التالية لحساب الطاقة الثمسية الممنصة:

$$
Q_{a}=0.818 Q,\left(R^{2}=0.999\right)
$$

* أستاذ ـ قسم الهندسة الزراعية ـكلية الزراعة ـ جامعة طنطا. * * مدرس - قسم الهندسة الزراعية كلية الزراعة -جامعة طنطا.

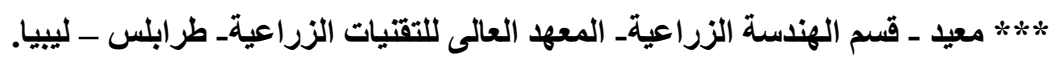

